\title{
Rhinos Belong to Everybody, by Bernhard Grzimek. Collins, 635.
}

If not a flood, there has been a steady flow of books on big game during recent years, and in particular on the great herds of the African plains. So much is published that is broadly similar that, enthusiast as I am, I find it difficult to struggle through most of it, and a cursory glance at the pictures is usually enough. Now at last here is a winner, a jewel in rather modest company, which is bound to absorb the most discerning reader, all the wildlife picture fans, lovers of travelogues and experts in conservation.

The pictures are outstanding. Some are breathtaking in their beauty, others dramatic or revealing as wildlife shots, and all of a special standard in terms of quality. If they could spring into movement as film sequences, $\mathrm{I}$, as an amateur television producer, would water at the mouth. But this is not the main point to be made. The first judgment must be that this is not a volume dressed up like so many others to justify the reproduction of wonderful pictures. The text is as important and valuable as the pictures, full of stories and experiences and many facts hitherto unrecorded.

Bernhard Grzimek is not only a prince of conservationists, but a great "fixer" in the political field. He has a sort of magnetism for people of all races and colour, commanding trust and respect wherever he puts in an oar. Thus his latest book is of special interest because he brings the library up to date on the game park position since independence in Africa, and describes his extraordinary efforts at intervention for the sake of wildlife in the Congo. It would never entirely surprise me to find him one day mediating between governments and rebels anywhere! Grzimek has a magic of his own.

This is probably because of his honesty of outlook and purpose. His approach to conservation, with a keen sense of science and reality, is unsentimental and courageous. He is the antithesis of the cuddly furry brigade, which cashes in on public ignorance and commercialises sentiment. Thus everyone comes to believe what he says and to accept what he proposes. No man has more influence as a conservationist, nor can achieve more for wildlife anywhere, than Bernhard Grzimek on the African continent, and any student or enthusiast is going to be out of touch if he has not had the latest Grzimek dispatch on the general situation.

AUBREY BUXTON

\section{Sauce for the Mongoose, by Bruce Kinloch. Harvill Press, 25s.}

This is the fascinating story of a pet African banded mongoose, Pipa, meaning " a barrel " in the local vernacular, so-called from his pot-belly, the result of habitual disgusting gluttony. Pipa's astonishing escapades are of bewildering diversity, and one marvels that so much mischief can derive from so small a body. Irascible, often painfully reinforcing his many whims and demands with needle-sharp teeth, he was also affectionate and most lovable, " a character out of all proportion to his size." $\mathrm{He}$ was incredibly fearless, but instinctively aware of danger from above and the avian predator always made him panic.

An ardent exponent of the personality cult, he became so domineering, exacting and destructive that banishment from civilisation was his inevitable lot. Then, suddenly and unexpectedly, after a mate had been found for him, he returned to the wild, and, in the sage words of the author, "the mongoose clans of the Serengeti are going to learn a lot from him." His most impressive performance was when he decided to accompany an African Ranger patrol on a three-day, 45-mile tour, which for his little pattering feet ceaselessly 
scurrying to and fro probably meant fully a hundred miles-a truly remarkable feat of energy and endurance. A highly entertaining and enjoyable book, profusely illustrated with the author's splendid and eloquent photographs.

\section{R. S. PITMAN}

\section{The World of the Tiger, by Richard Perry. Cassell, 30s.}

This is a book worth reading. For the most part it is accurate, and the subject has been well presented and developed, the result of considerable research. Many are the quotations and tales from other writers, some possibly true, others just exciting stories which I feel the author leaves to the judgment of readers with experience of tiger in India.

The author considers that there are now fewer than four thousand tigers in India, which I am sure is a low estimate; nor do I share his opinion that the end of this century will see India tigerless except for a few in sanctuaries and national parks. In spite of the extermination of deer by poachers in many parts, there is little risk of tiger disappearing. Its domains are in forests so vast, with areas difficult of access to the poacher, that it will still be found ranging over suitable areas for another century or so, and the Federal and State Governments are fully alive to the necessity of conserving existing forests. The author's observations about tiger never eating their kills in daylight are not wholly correct ; in fact instances to the contrary are quoted in his book. A tiger's "pooking" is, surely, a call of suspicion and uncertainty, far more likely to drive away sambhur than to attract them, and many readers will disagree with the author's conclusions on the tiger's sense of smell. Are there "alligators" in India? I think not ; crocodiles definitely. This reminds me of a little rhyme about a naturalist in India who, on being informed that his wife had been eaten by an " alligator", replied : "How very sad," and then with an engaging smile, " but I think you mean a crocodile!" The author is indeed fortunate in the photographs of tiger he has been able to include.

R. C. MORRIS

\section{The Management of Wild Animals in Captivity, by Lee S. Crandall. University of Chicago Press, 97 s.}

Many men swear that when they retire they will write a great book about their life's experiences. Unhappily few carry it out. Lee Crandall is the exception. This book on mammals in captivity is a model of objective summarising of a long life's work. Crandall, who joined the New York Zoo in 1908, remained there for over half a century, rising to the position of General Curator, and no one could be better qualified than he to produce a reference work of this kind.

Packed tight with information, it is arranged, not topic by topic, but family by family, following the taxonomic arrangements laid down by Simpson. If one is seeking details of a particular mammalian group or species, therefore, the book is of enormous value, but it is not so helpful when cross-sectional information on a mammalian topic or theme is wanted. For example, vital statistics such as body weights, measurements, longevities and breeding seasons are scattered all through the volume, arranged, like everything else, according to the taxonomic groupings. It is arguable that the book could have been less bulky if this kind of information had been tabulated in a few pages at the back (as has been done with the International 